\title{
SSTR3 wt Allele
}

National Cancer Institute

\section{Source}

National Cancer Institute. SSTR3 wt Allele. NCI Thesaurus. Code C51476.

Human SST R3 wild-type allele is located in the vicinity of 22q13.1 and is approximately 6 $\mathrm{kb}$ in length. This allele, which encodes somatostatin receptor type 3 protein, plays a role in the inhibition of adenylyl cyclase. 